\title{
Bacterial infections in cirrhosis
}

\author{
Guadalupe Garcia-Tsao MD
}

G Garcia-Tsao. Bacterial infections in cirrhosis. Can J Gastroenterol 2004;18(6):405-406.

Hospitalized patients with cirrhosis are at increased risk of developing bacterial infections, the most common being spontaneous bacterial peritonitis $(\mathrm{SBP})$ and urinary tract infections. Independent predictors of the development of bacterial infections in hospitalized cirrhotic patients are poor liver synthetic function and admission for gastrointestinal hemorrhage. Short term (seven-day) prophylaxis with norfloxacin reduces the rate of infections and improves survival and should therefore be administered to all patients with cirrhosis and variceal hemorrhage. Cirrhotic patients who develop abdominal pain, tenderness, fever, renal failure or hepatic encephalopathy should undergo diagnostic paracentesis, and those who meet the criterion for SBP (eg, an ascites neutrophil count greater than $250 / \mathrm{mm}^{3}$ ) should receive antibiotics, preferably a third-generation cephalosporin. In addition to antibiotic therapy, albumin infusions have been shown to reduce the risk of renal failure and mortality in patients with SBP, particularly in those with renal dysfunction and hyperbilirubinemia at the time of diagnosis. Patients who recover from an episode of SBP should be given long term prophylaxis with norfloxacin and should be assessed for liver transplantation.

\section{Les infections bactériennes en cas de cirrhose}

Les patients cirrhotiques hospitalisés risquent davantage de contracter des infections bactériennes, les plus courantes étant une péritonite bactérienne spontanée (PBS) et une infection urinaire. Des prédicteurs indépendants d'apparition d'infections bactériennes chez les patients cirrhotiques hospitalisés sont une mauvaise fonction synthétique du foie et une hospitalisation secondaire à une hémorragie gastro-intestinale. Une prophylaxie de courte durée (sept jours) à la norfloxacine réduit le taux d'infections et améliore la survie. Elle devrait donc être administrée à tous les patients souffrant de cirrhose et d'hémorragies variqueuses. Les patients cirrhotiques qui souffrent de douleurs et de sensibilité abdominales, de fièvre, d'insuffisance rénale ou d'encéphalopathie devraient subir une paracentèse diagnostique, et ceux qui respectent les critères de PBS (p. ex., une numération des neutrophiles ascitiques supérieure à $250 / \mathrm{mm}^{3}$ ) devraient recevoir des antibiotiques, de préférence une céphalosporine de troisième génération. Outre l'antibiothérapie, il a été établi que les infusions d'albumine réduisent le risque d'insuffisance rénale et de mortalité chez les patients atteints de PBS, surtout s'ils souffrent d'une dysfonction rénale et d'hyperbilirubinémie au moment du diagnostic. Les patients qui se remettent d'un épisode de PBS devraient recevoir une prophylaxie de longue durée à la norfloxacine et faire l'objet d'une évaluation pour recevoir une greffe hépatique.

Key Words: Cirrhosis; Gastrointestinal hemorrhage; Infections; Spontaneous bacterial peritonitis

$\mathrm{B}^{3}$

acterial infections are important causes of morbidity and mortality in patients with end-stage liver disease. Hospitalized patients with cirrhosis acquire bacterial infections at a higher rate than the general population (approximately $30 \%$ versus $6 \%$ ). The risk of developing bacterial infection is greater in cirrhotic patients with poor liver function and in those who are admitted for upper gastrointestinal (UGI) hemorrhage (1).

Infections have severe consequences for patients with liver disease. The development of bacterial infections is associated with failure to control bleeding (or rebleeding) and a higher mortality in patients with variceal hemorrhage $(2,3)$.

Antibiotic prophylaxis in the setting of variceal hemorrhage significantly decreases the incidence of bacterial infections and improves survival $(4,5)$. For this reason, the administration of short term antibiotic prophylaxis is now considered the standard of care for cirrhotic patients who are admitted with UGI bleeding. Several regimens have been utilized. The simplest and most cost effective schedule is oral norfloxacin $400 \mathrm{mg}$ twice a day for seven days.

Spontaneous bacterial peritonitis (SBP) and urinary tract infections are the most prevalent bacterial infections in patients with cirrhosis. SBP is defined as infection of the ascitic fluid in the absence of a contiguous source of infection (eg, intestinal perforation or abscess) (6). It occurs almost exclusively in patients with cirrhosis and is often accompanied by bacteremia. Defects in the reticuloendothelial system, resulting in decreased bacterial killing, play an important role in its pathogenesis (7). Risk factors for SBP include poor liver function, admission for gastrointestinal bleeding, a low ascites protein content (less than $1.0 \mathrm{~g} / \mathrm{dL}$ ), elevated bilirubin levels and thrombocytopenia $(1,8)$. The most frequent causative organisms are Gram-negative bacilli (7). Gram-positive cocci, however, are becoming increasingly prevalent in the intensive care setting and in patients who have undergone invasive procedures (9).

Yale University School of Medicine, New Haven, Connecticut, USA.

Presented at the $16^{\text {th }}$ International Course on Therapeutic Endoscopy, Toronto, Ontario, October 2003

Correspondence: Dr G Garcia-Tsao, Hepatologist, Yale University School of Medicine, 333 Cedar Street, 1080 LMP, New Haven, Connecticut

06520-8019, USA. Telephone 203-737-6060, fax 203-785-7273, e-mail guadalupe.garcia-tsao@yale.edu

Received and accepted for publication April 2004 
TABLE 1

Indications for diagnostic paracentesis in patients with cirrhosis

At admission for UGI bleeding or other liver-related complications

Abdominal signs or symptoms of SBP (pain, tenderness or ileus)

Fever or other systemic evidence of infection

Renal dysfunction

Hepatic encephalopathy

SBP Spontaneous bacterial peritonitis; UGI Upper gastrointestinal

Early diagnosis depends on a high index of suspicion (6). The presence of SBP should be suspected, and diagnostic paracentesis performed, if a patient with cirrhosis develops abdominal pain or tenderness, fever, renal dysfunction or hepatic encephalopathy (Table 1). Signs of peritonitis may be very subtle. The presence of a polymorphonuclear cell count greater than $250 / \mathrm{mm}^{3}$ in the ascites is diagnostic of SBP.

Early diagnosis and treatment have decreased the mortality rate from SBP, from greater than $80 \%$ in the 1970 s to approximately 25\% now (6). Treatment of SBP should be initiated before culture and sensitivity tests are available. Empiric therapy is generally commenced with third-generation cephalosporins or the combination of beta-lactam antibiotics and beta-lactamase (6). On the other hand, aminoglycosides should be avoided because of the increased risk of nephrotoxicity in cirrhotic patients.

The major complication of SBP is renal dysfunction, which is probably due to worsening of the vasodilatory state

\section{REFERENCES}

1. Deschenes M, Villeneuve JP. Risk factors for the development of bacterial infections in hospitalized patients with cirrhosis. Am J Gastroenterol 1999;94:2193-7.

2. Bernard B, Cadranel JF, Valla D, Escolano S, Jarlier V, Opolon P. Prognostic significance of bacterial infection in bleeding cirrhotic patients: A prospective study. Gastroenterology 1995;108:1828-34.

3. Goulis J, Armonis A, Patch D, Sabin C, Greenslade L, Burroughs AK. Bacterial infection is independently associated with failure to control bleeding in cirrhotic patients with gastrointestinal hemorrhage. Hepatology 1998;27:1207-12.

4. Bernard B, Grange JD, Khac EN, Amiot X, Opolon P, Poynard T. Antibiotic prophylaxis for the prevention of bacterial infections in cirrhotic patients with gastrointestinal bleeding: A meta-analysis. Hepatology 1999;29:1655-61.

5. Soares-Weiser K, Brezis M, Tur-Kaspa R, Leibovici L. Antibiotic prophylaxis for cirrhotic patients with gastrointestinal bleeding. Cochrane Database Syst Rev 2002;2:CD002907. that generally accompanies cirrhosis. This leads to decreased effective arterial blood volume, which in turn activates the renin-angiotensin system, thereby provoking renal vasoconstriction and decreasing glomerular filtration rate. Albumin infusions, because they increase effective arterial volume, decrease the risk of renal dysfunction and improve survival (10).

Patients who recover from an episode of SBP are at a much higher risk of recurrence of this condition, compared with those who have never developed SBP (approximately 70\% versus approximately $20 \%$ in one year). For this reason, long term prophylaxis with norfloxacin is warranted in these patients (11). Median survival in patients who develop SBP is approximately nine months. Therefore, this population should be promptly evaluated for liver transplantation.

\section{CONCLUSIONS}

Patients with severe liver disease accompanied by portal hypertension are at risk of developing SBP. Short term prophylactic antibiotics (oral norfloxacin) should be given to patients who are admitted with variceal bleeding. Patients with liver disease and ascites who develop signs of peritonitis, sepsis or hepatic or renal decompensation should undergo diagnostic paracentesis. A high neutrophil count in the ascitic fluid is diagnostic of SBP and warrants empiric antibiotic therapy. Albumin should be used in addition to antibiotics, particularly in patients with renal dysfunction at the time of diagnosis. Long-term prophylaxis is warranted only in patients who have recovered from an episode of SBP.

6. Rimola A, Garcia-Tsao G, Navasa M, et al. Diagnosis, treatment and prophylaxis of spontaneous bacterial peritonitis: A consensus document. International Ascites Club. J Hepatol 2000;32:142-53.

7. Garcia-Tsao G. Spontaneous bacterial peritonitis. Gastroenterol Clin N Am 1992;21:257-75.

8. Guarner C, Sola R, Soriano G, et al. Risk of a first communityacquired spontaneous bacterial peritonitis in cirrhotics with low ascitic fluid protein levels. Gastroenterology 1999;117:414-9.

9. Fernandez J, Navasa M, Gomez J, et al. Bacterial infections in cirrhosis: Epidemiological changes with invasive procedures and norfloxacin prophylaxis. Hepatology 2002;35:140-8.

10. Sort P, Navasa M, Arroyo V, et al. Effect of intravenous albumin on renal impairment and mortality in patients with cirrhosis and spontaneous bacterial peritonitis. N Engl J Med 1999;341:403-9.

11. Gines P, Rimola A, Planas R, et al. Norfloxacin prevents spontaneous bacterial peritonitis recurrence in cirrhosis: Results of a double-blind, placebo-controlled trial. Hepatology 1990;12:716-24. 


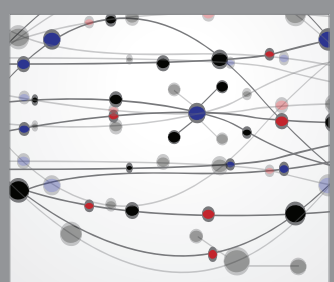

The Scientific World Journal
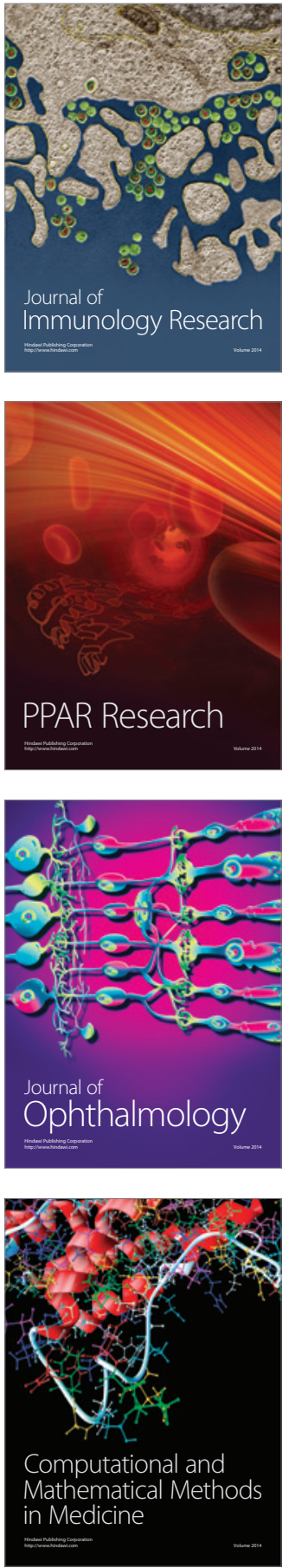

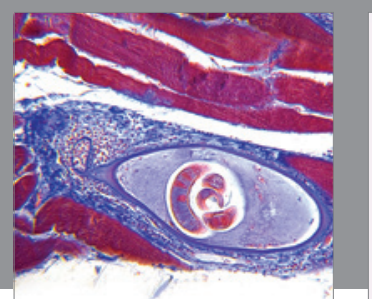

Gastroenterology Research and Practice

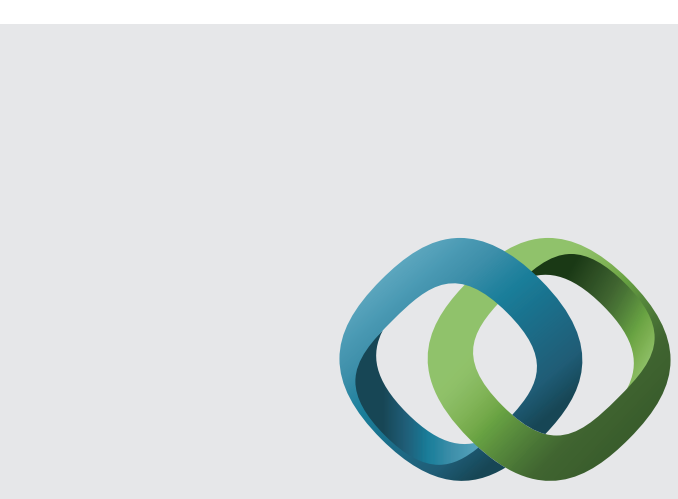

\section{Hindawi}

Submit your manuscripts at

http://www.hindawi.com
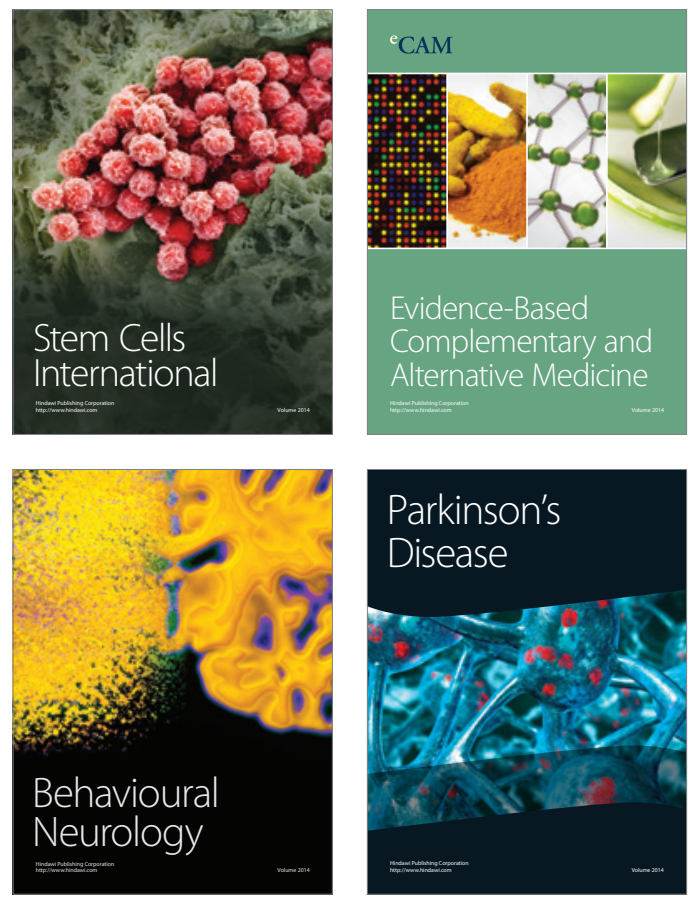
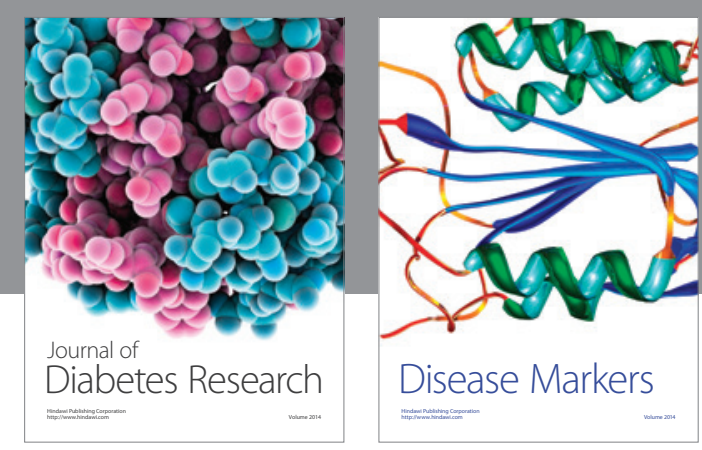

Disease Markers
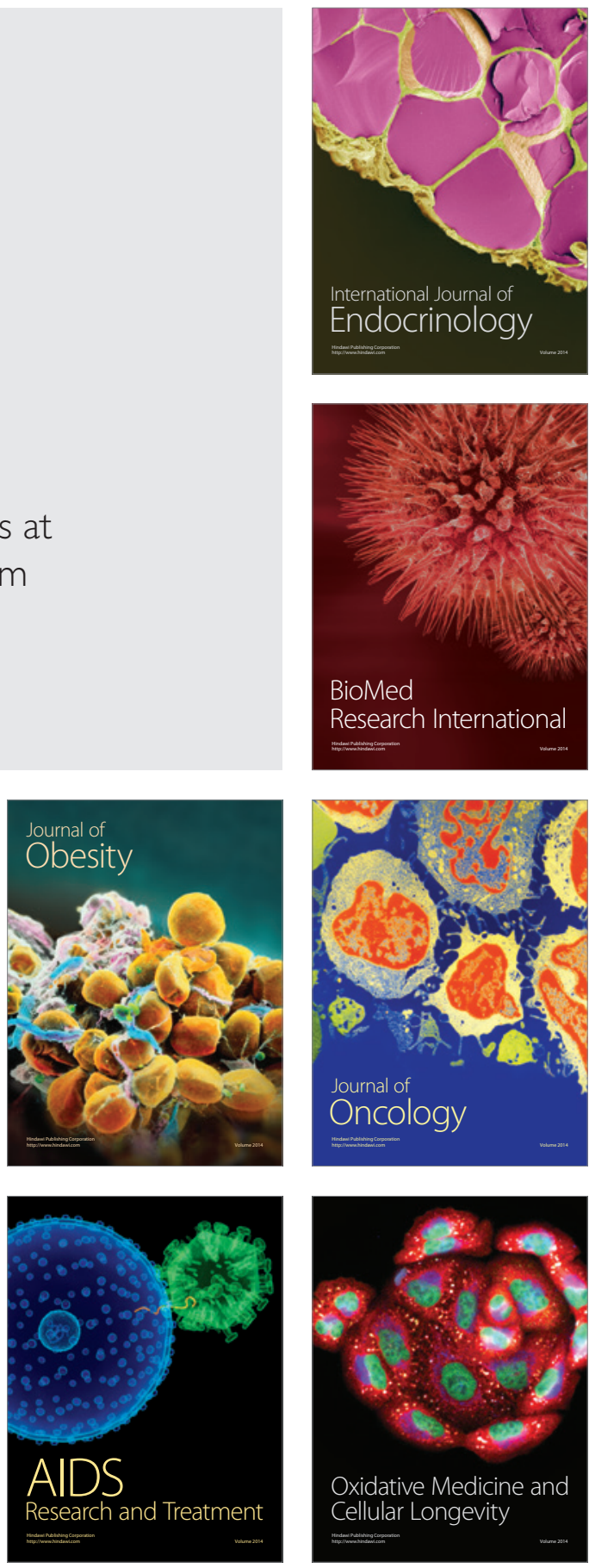